\title{
Revised Structure of Haemoventosin
}

\author{
David S. Rycroft ${ }^{\mathrm{a}}$, Joseph D. Connolly ${ }^{\mathrm{a}}$, Siegfried Huneck*, ${ }^{*}$, Uwe Himmelreich ${ }^{\mathrm{b}}$ \\ a Department of Chemistry, University of Glasgow, Glasgow G12 8QQ, Scotland, UK \\ ${ }^{b}$ Institute of Plant Biochemistry, PSF 250, D-06018 Halle/Saale, Germany \\ Z. Naturforsch. 50b, 1557-1563 (1995); eingegangen am 13. März 1995 \\ Haemoventosin, Naphthoquinone, Ophioparma ventosa, Lichen, ${ }^{1} \mathrm{H}$ NMR Spectra, \\ ${ }^{13} \mathrm{C}$ NMR Spectra \\ The structure of the lichen pigment haemoventosin has been revised to 3,4,6,9-tetrahydro- \\ 5,10-dihydroxy-7-methoxy-3 S-methyl-1,6,9-trioxo-1 H-naphtho-[2,3-c]pyran (3), mainly on \\ the basis of long-range $\delta_{\mathrm{C}} / \delta_{\mathrm{H}}$ correlations observed in $2 \mathrm{D}$ HMBC NMR experiments and \\ long-range $\delta_{\mathrm{H}} / \delta_{\mathrm{D}}$ isotope effects observed in partial deuteriation experiments with 10-O- \\ acetylhaemoventosin; ortho- and para-quinonoid structures were distinguished by means of \\ the transacetylation inferred in the sodium dithionite reduction of $10-O$-acetylhaemo- \\ ventosin.
}

\section{Introduction}

The crustose lichen Ophioparma ventosa (L.) Norman [syn. Haematomma ventosum (L.) Massal. (Lecanoraceae)] is characterized by blood red apothecia, the colour of which turns to blue on treatment with potassium hydroxide. Bruun and Lamvik [1] isolated the pigment (haemoventosin) of the apothecia and proposed structure $\mathbf{1}$ for this lichen metabolite. Twenty years later Maksimov et al. [2] put forward the alternative $o$-quinonoid structure $\mathbf{2}$ for haemoventosin which they isolated from Ophioparma lapponica (Rasänen) Hafellner \& R. W. Rogers (syn. Haematomma lapponicum Rasänen); this proposal relied on the formation with $o$-phenylene diamine of a derivative assumed to be a quinoxaline.

We have revised the structure of haemoventosin to the $p$-quinone- $\delta$-lactone $\mathbf{3}$, mainly on the basis of the results of extensive NMR experiments with the monoacetate of haemoventosin. Initially NMR experiments were performed at $4.7 \mathrm{~T}$; more recently an $11.7 \mathrm{~T}$ spectrometer was also used, and the sensitivity advantage of inverse experiments was applied to good effect.

The original structure of haemoventosin and its ${ }^{1} \mathrm{H}$ NMR spectrum were used as models when considering dihydrofuran isomeric possibiiities of some isofuranonaphthoquinones [3]; such compar-

\footnotetext{
* Reprint requests to S. Huneck, Fliederweg $34 \mathrm{a}$, D-06179 Langenbogen, BRD.
}

isons are invalid as haemoventosin does not contain a dihydrofuran.

\section{Results and Discussion}

We have isolated haemoventosin from $O$. ventosa from Bulgaria and Mongolia and have investigated this compound and its monoacetate using IR, ${ }^{1} \mathrm{H}$ and ${ }^{13} \mathrm{C} \mathrm{NMR}$, and $\mathrm{CD}$ spectroscopy.

Haemoventosin is not very soluble in the normal spectroscopic solvents, but forms a monoacetate 4 which is more amenable to spectroscopic investigation in solution. Reaction of haemoventosin with acetic anhydride/sulphuric acid gave a product whose physical properties corresponded to those reported for the monoacetate prepared using acetic anhydride/pyridine [1]. Monoacetylhaemoventosin reveals in the carbonyl region of the IR spectrum bands at 1716 (quinone CO) and $1750 \mathrm{~cm}^{-1}$. The latter band is incompatible with $\mathbf{1}$ and $\mathbf{2}$, but points to a $\delta$-lactone ring, connected to the naphthoquinone.

The ${ }^{1} \mathrm{H}$ NMR spectrum $(200 \mathrm{MHz})$ of monoacetylhaemoventosin at ambient temperature showed one aromatic and one hydroxyl proton, an acetate, a secondary methyl and a methoxyl group. The signals anticipated for the $\mathrm{CH}_{2} \mathrm{CH}$ moiety were unexpectedly broad; the secondary methyl signals were also broad and appeared to show an asymmetric doubling. In an attempt to remove the presumed exchange-broadening, the ${ }^{1} \mathrm{H}$ spectrum was measured at $333 \mathrm{~K}$; the signals sharpened, although the methine signal at $\delta 4.61\left(\mathrm{~W}_{1 / 2} 24 \mathrm{~Hz}\right)$ was still 


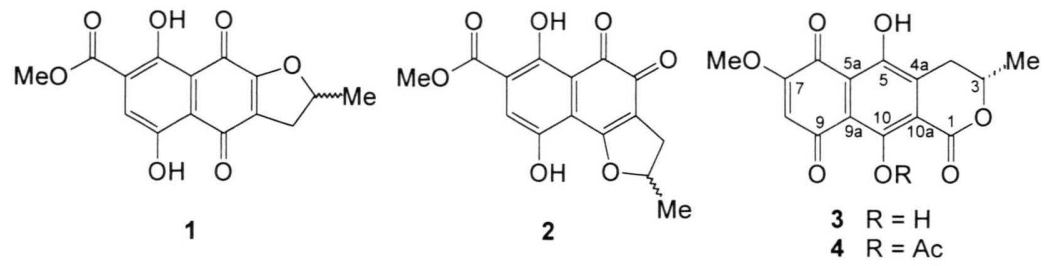

broad and featureless. Surprisingly the methoxyl signal in the $333 \mathrm{~K}$ spectrum appeared as a symmetrical doublet, splitting $0.4 \mathrm{~Hz}$, and the aromatic proton was a quartet with the same splitting; this immediately suggested that haemoventosin contained an aromatic methyl ether rather than a methyl ester. The ${ }^{13} \mathrm{C}$ NMR spectrum $(50 \mathrm{MHz})$ of monoacetylhaemoventosin at ambient temperature showed broadening and asymmetric doubling of some signals, and some quaternary aromatic signals were missing (compared to the molecular formula). At $333 \mathrm{~K}$ some of the signals collapsed to sharp singlets, but the higher temperature exacerbated the relaxation time problems associated with observing weak quaternary aromatic carbon signals and several were still missing. On the other hand at $243 \mathrm{~K}$ the spectrum improved and signals for 17 carbon atoms were ob- served, of which all except 3 were doubled in a $c a$. $2: 1$ ratio; it was also possible to measure the direct and long-range ${ }^{13} \mathrm{C},{ }^{1} \mathrm{H}$ coupling constants for the major isomer from a spectrum obtained with the proton decoupler switched off. Evidently at ambient temperature there is an exchange process occurring at an intermediate rate on the NMR timescale. At $243 \mathrm{~K}$ the ${ }^{1} \mathrm{H}$ NMR spectrum showed doubling of all the signals, also in a $c a$. 2:1 ratio; both protons of the $\mathrm{CH}_{2}$ group appeared as doublets of doublets for both conformers, but with slightly different coupling constants; homodecoupling of the methoxyl signals confirmed the presence of spin-spin coupling to the aromatic proton. The NMR data are given in Table I.

The carbons in the neighbourhood of the hydroxyl group were identified by measurement at ambient temperature of deuterium isotope effects

Table I. ${ }^{1} \mathrm{H}$ and ${ }^{13} \mathrm{C}$ NMR parameters ${ }^{\mathrm{a}}$ of monoacetylhaemoventosin ${ }^{\mathrm{b}}(\mathbf{4})$.

\begin{tabular}{|c|c|c|c|c|c|c|c|c|c|c|}
\hline Position & $\begin{array}{l}\text { Major } \\
\text { conformer } \\
\delta_{\mathrm{H}}\end{array}$ & $\begin{array}{l}\text { Minor } \\
\text { conformer } \\
\delta_{\mathrm{H}}\end{array}$ & $\begin{array}{l}\text { Proton } \\
\text { mult. }\end{array}$ & $\begin{array}{l}\text { Major } \\
\text { conformer } \\
J \\
(\mathrm{~Hz})\end{array}$ & $\begin{array}{l}\text { Minor } \\
\text { conformer } \\
J \\
(\mathrm{~Hz})\end{array}$ & $\begin{array}{l}\text { Major } \\
\text { conformer } \\
\delta_{\mathrm{C}}\end{array}$ & $\begin{array}{l}\text { Minor } \\
\text { conformer } \\
\delta_{\mathrm{C}}\end{array}$ & $\begin{array}{l}\text { Carbon } \\
\text { mult. }\end{array}$ & $\begin{array}{l}J \\
(\mathrm{~Hz})\end{array}$ & $\begin{array}{l}\Delta \delta_{\mathrm{C}} \\
(\mathrm{OH}-\mathrm{OD}) \\
(\mathrm{ppb})^{\mathrm{c}}\end{array}$ \\
\hline 1 & & & & & & 159.79 & 159.97 & s & & \\
\hline $3 \beta$ & 4.578 & 4.7 & $\mathrm{~m}$ & & & 74.54 & 74.29 & $\mathrm{dm}$ & 149 & \\
\hline $4 \alpha$ & 2.674 & 2.763 & $\mathrm{dd}$ & $\begin{array}{l}17.7 \\
12.2\end{array}$ & $\begin{array}{l}17.7 \\
10.7\end{array}$ & 28.75 & 28.39 & $\mathrm{tm}$ & 132 & \\
\hline $4 \beta$ & 3.321 & 3.303 & dd & $\begin{array}{r}17.7 \\
2.7\end{array}$ & $\begin{array}{r}17.7 \\
3.3\end{array}$ & & & & & \\
\hline $4 \mathrm{a}$ & & & & & & 137.89 & 137.54 & qd & 8,3 & 120 \\
\hline $5-\mathrm{OH}$ & 12.502 & 12.491 & $\mathrm{~s}$ & & & 156.13 & 156.21 & dd & 5,2 & 277 \\
\hline $\begin{array}{l}5 \mathrm{a} \\
6\end{array}$ & & & & & & $\begin{array}{l}115.54 \\
184.94\end{array}$ & 115.65 & $\begin{array}{l}\mathrm{d} \\
\mathrm{d}\end{array}$ & $\begin{array}{l}5 \\
8\end{array}$ & 71 \\
\hline 7 & & & & & & 158.20 & 158.16 & quin & 4 & \\
\hline 8 & 6.094 & 6.098 & $\mathrm{q}$ & 0.3 & 0.3 & 112.68 & & d & 166 & 24 \\
\hline $9 \mathrm{a}$ & & & & & & 121.28 & 121.02 & $\mathrm{~d}$ & 5 & \\
\hline 10 & & & & & & 142.74 & 142.43 & d & 1 & \\
\hline $10 \mathrm{a}$ & & & & & & 126.38 & 126.53 & $\mathrm{~d}$ & 5 & \\
\hline $3-\mathrm{Me}$ & 1.544 & 1.510 & $\mathrm{~d}$ & 6.4 & 6.4 & 20.66 & 20.47 & $\mathrm{qm}$ & 128 & \\
\hline 7-OMe & 3.890 & 3.892 & $\mathrm{~d}$ & 0.3 & 0.3 & 56.80 & & $\mathrm{q}$ & 147 & \\
\hline $\mathrm{OCO} \underline{\mathrm{Me}}$ & 2.420 & 2.423 & $\mathrm{~S}$ & & & 20.89 & 21.08 & $\mathrm{q}$ & 130 & \\
\hline $\mathrm{OCO} \overline{\mathrm{Me}}$ & & & & & & 169.54 & 170.01 & $\mathrm{q}$ & 7 & \\
\hline
\end{tabular}

a Shifts relative to $\mathrm{CHCl}_{3}$ at $\delta_{\mathrm{H}} 7.25$ and $\mathrm{CDCl}_{3}$ at $\delta_{\mathrm{C}} 77.0 ;{ }^{\mathrm{b}} \mathrm{CDCl}_{3}$ solution, $243 \mathrm{~K}, 4.7 \mathrm{~T}$; ${ }^{\mathrm{c}}$ isotope shifts, at 297 K (see text). 
in the ${ }^{13} \mathrm{C}$ spectrum $(50 \mathrm{MHz})$ of monoacetylhaemoventosin where the hydroxyl group had been partially deuteriated by shaking a $\mathrm{CDCl}_{3}$ solution with 3 drops of $\mathrm{H}_{2} \mathrm{O}$ and 2 drops of $\mathrm{D}_{2} \mathrm{O}[4,5]$. The isotope shifts observed are included in the Table I. The largest isotope shift $\Delta \delta_{\mathrm{C}}(\mathrm{OH}-\mathrm{OD})$ is $277 \mathrm{ppb}$ (for the signal at $\delta_{\mathrm{C}} 156.1$ ) and is associated with the carbon bearing the hydroxyl group.

The assignments of the protons at C-4, C-3 and Me-3 were confirmed by $\mathrm{H} / \mathrm{H}$ COSY at $500 \mathrm{MHz}$ $(11.7 \mathrm{~T})$. The correlations of the carbon atoms at 4, 3, Me-3, the methoxyl, and the acetate methyl group with their attached protons observed in a proton-detected heteronuclear direct $\delta_{\mathrm{C}} / \delta_{\mathrm{H}}$ correlation experiment at $11.7 \mathrm{~T}$ (HMQC [6]) confirmed the conclusions derived from the coupled ${ }^{13} \mathrm{C}$ spectrum. Correlations in the ROESY spectrum $(11.7 \mathrm{~T})$ confirmed the proximity of the 7-OMe protons and $\mathrm{H}-8$.

To prove the connectivity and to assign the quaternary carbon astoms we performed $2 \mathrm{D}$ longrange $\delta_{\mathrm{C}} / \delta_{\mathrm{H}}$ correlation experiments. The COLOC experiment had recently been published [7] when we started this work; however a COLOC spectrum obtained at $328 \mathrm{~K}$ and $4.7 \mathrm{~T}$ displayed correlations
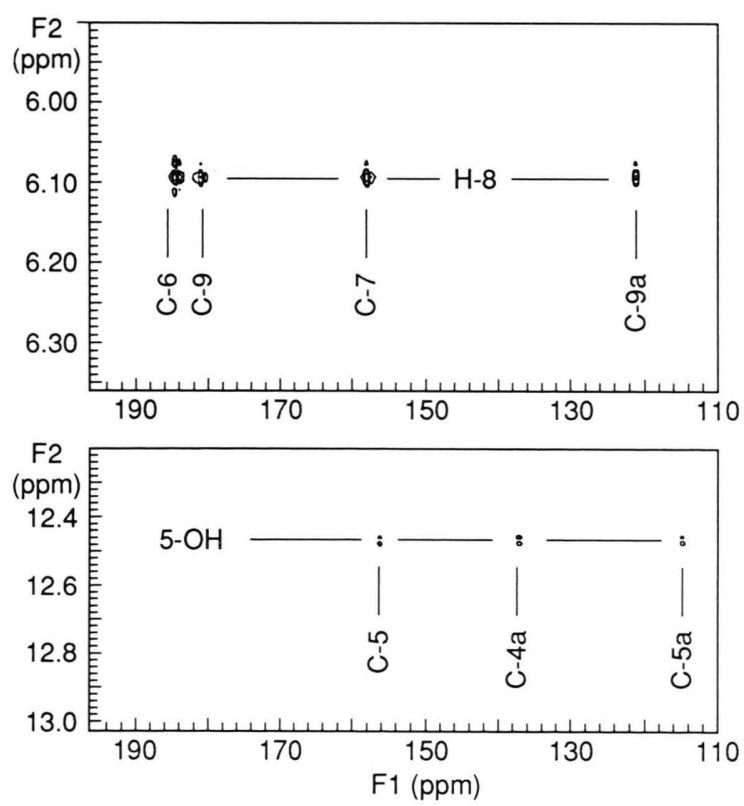

Fig. 1. Deshielded region of the inverse-detected longrange ${ }^{1} \mathrm{H} /{ }^{13} \mathrm{C}$ HMBC NMR spectrum of monoacetylhaemoventosin (4) in $\mathrm{CDCl}_{3}$. The delay $\tau_{1}$ was set appropriate to the value of ${ }^{1} J_{\mathrm{CH}}$, and $\tau_{2}$ was set to $140 \mathrm{~ms}$.
Table II. Logical sequence for the deduction of the bond connectivity of monoacetylhaemoventosin using correlations from HMBC spectra and other information.

\begin{tabular}{|c|c|}
\hline $\begin{array}{l}\text { Signals which show correlation } \\
\text { [or other observed fact] }\end{array}$ & Bond deduced \\
\hline $\begin{array}{l}\mathrm{H}-3 \text { with } \mathrm{H}-4 \quad(\mathrm{COSY}) \\
\mathrm{H}-3 \text { with } 3-\mathrm{CH}_{3} \quad(\mathrm{COSY}) \\
{\left[\Delta \delta_{\mathrm{C}}(\mathrm{OH}-\mathrm{OD}) \mathrm{C}-5=277 \mathrm{ppb}\right]} \\
\mathrm{HO}-5 \text { with } \mathrm{C}-5\end{array}$ & $\begin{array}{l}\mathrm{C}-3 \text { to } \mathrm{C}-4 \\
\mathrm{C}-3 \text { to } 3-\mathrm{CH}_{3} \\
\mathrm{HO}-5 \text { to } \mathrm{C}-5 \\
\text { (2-bond } \\
\text { coupling) }\end{array}$ \\
\hline $\begin{array}{l}\mathrm{HO}-5 \text { with } \mathrm{C}-4 \mathrm{a} \\
\mathrm{HO}-5 \text { with } \mathrm{C}-5 \mathrm{a} \\
\mathrm{C}-5 \text { with } \mathrm{H}-4 \\
\mathrm{C}-4 \mathrm{a} \text { with } \mathrm{H}-4 \\
{[\delta(\mathrm{H}-3)=4.578]} \\
\mathrm{C}-10 \text { a with } \mathrm{H}-4 \\
\mathrm{C}-1 \text { with } \mathrm{H}-3 \\
{\left[\Delta \delta_{\mathrm{C}}(\mathrm{OH}-\mathrm{OD}) \mathrm{C}-6=71 \mathrm{ppb}\right]} \\
\mathrm{C}-7 \text { with } 7-\mathrm{OCH} \mathrm{H}_{3} \\
7-\mathrm{OC} \underline{\mathrm{H}}_{3} \text { with } \mathrm{H}-8 \quad(\mathrm{ROESY}) \\
\mathrm{H}-8 \text { with C-7 }\end{array}$ & $\begin{array}{l}\text { C-5 to C- } 4 \text { a } \\
\text { C-5 to C-5 a } \\
\text { C-4 a/5 a to C-4 } \\
\text { C- } 4 \text { a to C-4 } \\
\text { C-3 to O-2 } \\
\text { C- } 10 \text { a to C-4 a } \\
\text { C-1 to O-2 } \\
\text { C-5 a to C-6 } \\
\text { C-7 to O-7 } \\
\text { C-7 to C-8 } \\
\text { (2-bond } \\
\text { coupling) }\end{array}$ \\
\hline $\begin{array}{ll}\text { H-8 with C-9 } & \left(\tau_{2}=140 \mathrm{~ms}\right) \\
& (2 \text {-bond coupling })\end{array}$ & C-8 to C- 9 \\
\hline $\begin{array}{ll}\text { H-8 with } \mathrm{C}-6 & \left(\tau_{2}=70 \mathrm{~ms}\right) \\
& (3 \text {-bond coupling })\end{array}$ & C-7/9 to C-6 \\
\hline $\begin{array}{l}\text { H-8 with C-9a } \\
{[\delta(\mathrm{C}-10)=142.74]}\end{array}$ & $\begin{array}{l}\text { C }-9 / 7 \text { to } \mathrm{C}-9 \mathrm{a} \\
\text { C- }-10 \text { to OAc }\end{array}$ \\
\hline
\end{tabular}

corresponding to only some of the couplings observed in the proton-coupled carbon spectrum. In contrast inverse HMBC experiments [8] performed at ambient temperature and $11.7 \mathrm{~T}$ displayed more correlations; with the delay $\tau_{2}$ set to $70 \mathrm{~ms}$ the largest correlations should arise from long-range $\mathrm{C}, \mathrm{H}$ coupling constants of $\mathrm{ca} .7 \mathrm{~Hz}$ (a typical value for 3-bond couplings in aromatic compounds, 2-bond couplings having smaller values) whereas with $\tau_{2}$ set to $140 \mathrm{~ms}$ the largest correlations should arise from couplings of $c a .3 \mathrm{~Hz}$; all these correlations are assumed to arise from 2- and 3-bond interactions. The deshielded proton region of the HMBC spectrum of monoacetylhaemoventosin with $\tau_{2}=140 \mathrm{~ms}$ is shown in Fig. 1 .

A sequence for the logical extension of the bond connectivity is be presented in Table II and this reasoning results in the fragments shown as structures 5 or $\mathbf{6}$. The onyl geometrically reasonable structures produced by connecting the free bonds are $\mathbf{4}, \mathbf{7}, \mathbf{8}$, and $\mathbf{9}$. We have been unable to find examples of structures closely related to $\mathbf{8}$ and $\mathbf{9}$. One would expect the hydrogen bond in the indene ring system to be weaker than that in the naphthalene system; the closest analogues we 
could find were related to dengibsin $\mathbf{1 0}$ [9], a derivative of 1-hydroxy-9-fluorenone, where the chemical shift of the hydrogen-bonded phenolic proton is always close to $\delta_{\mathrm{H}} 9$. The hydroxyl proton chemical shift in monoacetylhaemoventosin $\left(\delta_{\mathrm{H}} 12.5\right)$ suggests the presence of a much stronger hydrogen bond than in $\mathbf{1 0}$ and indeed $\delta_{\mathrm{H}}$ of a perihydrogen-bonded hydroxyl proton is typically around $13 \mathrm{ppm}$ in naphthoquinones $[10,11]$. Hence structures 8 and $\mathbf{9}$ are rejected. The question of deciding between the para- and ortho-quinonoid nature of structures $\mathbf{4}$ and $\mathbf{7}$ was resolved by noting that dithionite reduction [10] of $10-O$ acetyl-semi-xanthomegnin $\mathbf{1 1}$ did not produce the expected hydroquinone $\mathbf{1 2}$ but rather $\mathbf{1 3}$, in which transesterification had occurred to produce a hydroxyl group strongly hydrogen-bonded $\left(\delta_{\mathrm{H}} 13.04\right)$ to the lactone carbonyl group. In the case of structure 4 similar behaviour might be expected to produce $\mathbf{1 4}$ (with a strongly dishielded hydroxyl proton) whereas in the reduction of structure 7 it would not be possible for intramolecular transesterification to occur and the product $\mathbf{1 5}$ would not show any strongly deshielded hydroxyl protons. Reduction of monoacetylhaemoventosin was carried out in an NMR tube; a dilute $\mathrm{CDCl}_{3}$ solution was shaken with drops of aqueous sodium dithionite solution, which was added until the colour change from yellow-orange to pale yellow indicated that reduction was complete. Intermediate stages were monitored by observing the ${ }^{1} \mathrm{H}$ NMR spectrum $(200 \mathrm{MHz})$; the spectrum of monoacetylhaemoventosin was steadily and cleanly replaced by that of a new species with three phenol groups
[ $\delta_{\mathrm{H}} 12.53$ (sharp), 8.78 (broad), and 6.56 (broad)], assigned structure $\mathbf{1 4}$ on account of the signal at $\delta_{\mathrm{H}}$ 12.53. When the aqueous layer was pipetted off and the $\mathrm{CDCl}_{3}$ solution washed with water the colour changed to pale pink-orange and the broad phenolic proton signals sharpened slightly but the spectrum was otherwise essentially unchanged. Hence monoacetylhaemoventosin is assigned the para-quinonoid structure $\mathbf{4}$. $\mathrm{H}-8$ is deshielded in 14 compared to 4 and the chemical shift $\left(\delta_{\mathrm{H}} 6.85\right)$ is the same as in $\mathbf{1 3}$ [10]. In contrast to $\mathbf{4}$ the signals for the $\mathrm{CH}_{2} \mathrm{CHCH}_{3}$ moiety in $\mathbf{1 4}$ are sharp at ambient temperature $\left[\delta_{\mathrm{H}} 1.54(3 \mathrm{H}-11, \mathrm{~d}, J 6.3 \mathrm{~Hz})\right.$, 2.68 (H-4 $\alpha$, dd, $J 16.7,11.1 \mathrm{~Hz}), 3.30$ (H-4 $\beta$, dd, $J$ $16.7,3.3 \mathrm{~Hz}), 4.64(\mathrm{H}-3, \mathrm{~m})]$; the remaining signals are $\delta_{\mathrm{H}} 2.37$ (OAc, s) and $4.00(\mathrm{OMe}, \mathrm{s})$.

Haemoventosin has a centre of chirality at C-3 and should be optically active. Bruun and Lamvik [1] did not report the optical rotation of haemoventosin or its acetate. We found that monoacetylhaemoventosin indeed is optically active; it has the large specific rotation of $[\alpha]_{578}{ }^{24}+354.5$ and the $\mathrm{CD}$ spectrum is shown in Fig. 2, along with that of 10 - $O$-acetyl-semi-xanthomegnin (11). The two CD spectra are nearly mirror images of each other. 11 has been shown to have the $3 R$ configuration by comparison with $R$-mellein [10], and therefore 4 has the $3 S$ configuration; the additional hydroxyl group at C-5 should have little influence on the $\mathrm{CD}$ of $\mathbf{4}$ in comparison to $\mathbf{1 1}$. Hence haemoventosin is 3,4,6,9-tetrahydro-5,10-dihydroxy-7-methoxy-3 $S$-methyl-1,6,9-trioxo-1 H-naphtho[2,3-c]pyran $\mathbf{3}$ and monoacetylhaemoventosin is the corresponding $10-O$-acetate 4 . A related naphthoqui-

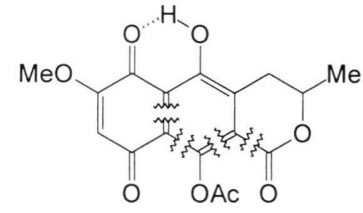

5<smiles>COC1=CC(=O)c2c(O)c3c(c(O)c2C1=O)C[C@H](C)OC3=O</smiles>

8

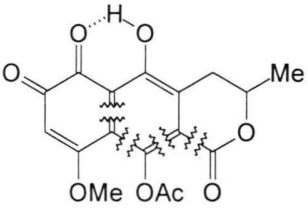

6

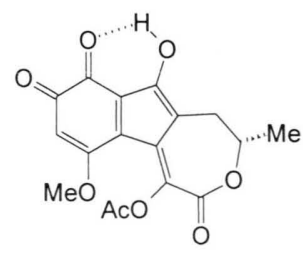

9<smiles>COc1cc(=O)cc(OC)c2c(O)c3c(c(O)c12)C[C@H](C)OC3=O</smiles>

7

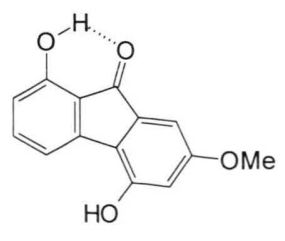

10 
<smiles>[M]C1Cc2cc3c(c(OC(C)=O)c2C(=O)O1)C(=O)C=C(OC)C3=O</smiles>

11<smiles>COc1cc(O)c2c(OC(C)=O)c3c(cc2c1O)CC(C)OC3=O</smiles>

12<smiles>COc1cc(OC(C)=O)c2c(O)c3c(cc2c1O)CC(C)OC3=O</smiles>

13<smiles>COc1cc(OC(C)=O)c2c(O)c3c(c(O)c2c1O)C[C@@H](C)OC3=O</smiles>

14<smiles>COc1cc(O)c(O)c2c(O)c3c(c(OC(C)=O)c12)C(=O)O[C@H](C)C3</smiles>

15

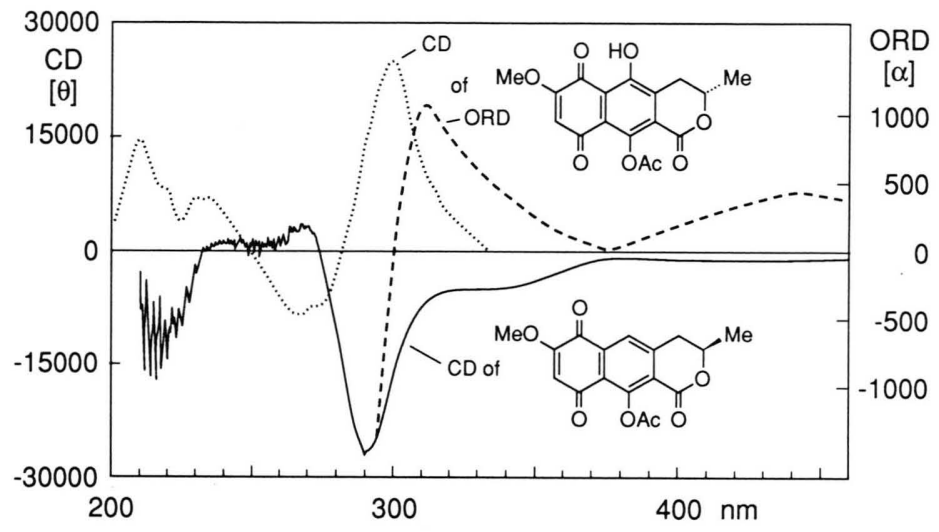

Fig. 2. CD spectra of $10-O$-acetylhaemoventosin (4, in $\mathrm{MeCN})$ and 10-O-acetylsemi-xanthomegnin (11, in $\mathrm{MeOH})$, and ORD curve of $\mathbf{4}$ (in $\mathrm{MeOH}$ ).

none, anhydrofusarubin lactone $\mathbf{1 6}$, has been isolated from the fungus Nectria haematococca [11]; the structure has been shown variously, without discussion, as both 16a [11] and 16b [12].

The finding of Bruun and Lamvik [1] that haemoventosin can be hydrolyzed with $10 \%$ $\mathrm{NaOH}$ to a compound, m.p. $c a .200{ }^{\circ} \mathrm{C}$, with the formula $\mathrm{C}_{14} \mathrm{H}_{10} \mathrm{O}_{7}$ (found $\mathrm{M}^{+} 290.0429$ ), which led to the proposal of a methyl ester in $\mathbf{1}$, deserves comment. This simple saponification is still readily accounted for in the revised structure $\mathbf{3}$, as it con-<smiles>COc1cc(O)c2c(c1O)C(=O)c1cc(C)oc(=O)c1C2=O</smiles>

$16 a$<smiles>COC1=CC(=O)c2c(c(O)c3cc(C)oc(=O)c3c2O)C1=O</smiles>

$16 b$ tains a vinylogous ester moiety, marked by a dotted line in formula 17. The product of hydrolysis is therefore $\mathbf{1 8 .}$<smiles>CCC(=O)c1c(O)c2c(c(O)c1C(=O)OC)C[C@H](C)OC2=O</smiles>

17 (3)<smiles>C[C@H]1Cc2c(O)c3c(c(O)c2C(=O)O1)C(=O)C=C(O)C3=O</smiles>

18

\section{Conformation isomerism}

The exchange process referred to earlier that results in broadening of the NMR spectra of $\mathbf{4}$ can now be understood in terms of conformational isomerism about the C-10 to acetate bond. Steric hindrance exerted by the peri-oxygen atoms of the $\mathrm{C}-1$ and C-9 carbonyl groups will force the 10-O- 
acetyl group to lie either above or below the plane of the aromatic ring, the faces of which are rendered inequivalent by the chiral centre C-3. The steric hindrance which causes the conformational isomerism is evidently sufficient to slow the rate of conformational interchange to one that is intermediate on the NMR timescale at ambient temperatures. This view is consistent with the observation that the ${ }^{1} \mathrm{H}$ NMR spectrum of the reduction product $\mathbf{1 4}$ is sharp at ambient temperature: in $\mathbf{1 4}$ the 9-O-acetyl group has a peri-interaction with only one oxygen atom and conformational interchange is not restrained.

It is noteworthy that Bruun and Lamvik [1] gave few details of the ${ }^{1} \mathrm{H}$ NMR spectrum of monoacetylhaemoventosin; similarly Zeeck et al. [10] did not report any ${ }^{1} \mathrm{H}$ NMR data for $10-O$-acetyl-semixanthomegnin 11, which might be expected to display similar conformational behaviour to $\mathbf{4}$, and similar complications in the NMR spectra.

\section{Chemotaxonomy}

According to Rogers and Hafellner [13] the genus Haematomma comprises two groups, the ochroleucum group and the puniceum group, from which the superficially similar genus Ophioparma has been separated. Ophioparma differs from Haematomma in its ecology, anatomy of the apothecia and chemistry (Haematomma with atranorin, Ophioparma without atranorin but with thamnolic acid). There is another important difference between the two genera, viz. the nature of the pigments from the apothecia. We have found the anthraquinones haematommone (19) and nemetzone (20) in the apothecia of Haematomma puniceum (Ach.) Massal. [14] and Haematomma nemetzii Steiner [15] respectively, while the apothecia of Ophioparma ventosa and Ophioparma lapponica contain the naphthoquinone haemoventosin [1,2, this paper]. The chemotaxonomy is interesting in that the biosynthesis of the pigments starts from related, but different, precursors: haemoventosin is derived from a heptaketide<smiles>[R]Oc1cc(O)c2c(c1)C(=O)c1cc(O[R])c(C(C)=O)c([R7])c1C2=O</smiles>

$\begin{array}{cccc} & \text { R } & R^{\prime} & R^{\prime \prime} \\ 19 & \text { H } & \text { H } & \text { OH } \\ 20 & \text { Me } & \text { Ac } & \text { H }\end{array}$

whereas haematommone and nemetzone are derived from an octaketide.

The apothecia play a very important role in the reproduction of lichens, but little is known, unfortunately, about the significance of the pigments. Ophioparma ventosa contains, according to TLC analysis, numerous other red pigments in its apothecia. These minor components, which could not be isolated in a pure state because of the small quantities, will be investigated further after collection of fresh lichen material.

Ophioparma ventosa seems to exist in at least two chemical races: one (from Bulgaria) contains haemoventosin, (+)-usnic acid, and divaricatic acid, whereas the other (from Mongolia) contains haemoventosin, (+)-usnic acid, and diffractaic acid. The lipid fraction (mainly a mixture of glycerides) of the extract from the Mongolian collection was saponified, the acid part methylated with diazomethane, and the mixture of methyl esters analysed by GLC and MS. The following fatty acids were found: tridecadienic, hexadecatrienic, palmitic, linolic, oleic, stearic, nonadecenic, arachidic, and behenic acids.

\section{Experimental}

NMR experiments were performed with Bruker WP200SY and AM200SY instruments (4.7 T) operating at $200.13\left({ }^{1} \mathrm{H}\right)$ and $50.325\left({ }^{13} \mathrm{C}\right) \mathrm{MHz}$, and with a Varian UNITY 500 spectrometer $(11.7 \mathrm{~T})$ operating at $499.85\left({ }^{1} \mathrm{H}\right)$ and $125.7\left({ }^{13} \mathrm{C}\right) \mathrm{MHz}$. Solutions of monoacetylhaemoventosin $(0.03 \mathrm{~g}$ at $4.7 \mathrm{~T}, 0.01 \mathrm{~g}$ at $11.7 \mathrm{~T})$ in $\mathrm{CDCl}_{3}(0.5 \mathrm{ml})$ were used. Chemical shifts are referred to internal $\mathrm{CHCl}_{3}\left(\delta_{\mathrm{H}} 7.25\right)$ and $\mathrm{CDCl}_{3}\left(\delta_{\mathrm{C}} 77.00\right)$ for ${ }^{1} \mathrm{H}$ and ${ }^{13} \mathrm{C}$ spectra respectively. $2 \mathrm{D} \mathrm{H} / \mathrm{H}$ COSY-90 spectra were recorded according to standard pulse programs. Direct $\delta_{\mathrm{H}} / \delta_{\mathrm{C}}$ correlation was achieved with the $2 \mathrm{D}{ }^{1} \mathrm{H}$-detected heteronuclear multiple quantum coherence experiment (HMQC); fixed delays were set for ${ }^{1} J_{\mathrm{CH}}=160 \mathrm{~Hz}$. Long-range $\delta_{\mathrm{H}} /$ $\delta_{\mathrm{C}}$ correlation came from $2 \mathrm{D}{ }^{1} \mathrm{H}$-detected heteronuclear multiple bond connectivity experiments (HMBC) using the pulse sequence RD-90 $\left({ }^{1} \mathrm{H}\right)$ $\tau_{1}-90^{\circ}\left({ }^{13} \mathrm{C}\right)-\tau_{2}-90^{\circ}\left({ }^{13} \mathrm{C}\right)-\mathrm{t}_{1} / 2-180^{\circ}\left({ }^{1} \mathrm{H}\right)-\mathrm{t}_{1} / 2-90^{\circ}\left({ }^{13} \mathrm{C}\right)-$ $\mathrm{t}_{2}\left(\right.$ acquire $\left.{ }^{1} \mathrm{H}\right)$ the delay $\tau_{1}$ was set for ${ }^{1} J_{\mathrm{CH}}=160$ $\mathrm{Hz}$, and $\tau_{2}$ was set to $70 \mathrm{~ms}$ or $140 \mathrm{~ms}$ to give maximum correlation intensity for long-range $J_{\mathrm{CH}}$ of $c a .7 \mathrm{~Hz}$ or $c a .3 \mathrm{~Hz}$ respectively.

Ophioparma ventosa. Voucher specimens of $O$. ventosa are deposited at the botanical Museum in Berlin-Dahlem (B). Origin: (a) Bulgaria, Witoscha 
Mountains, Malak Rezen, on granitic rocks, alt. $c a$. 2000 m; leg. et det. S. Huneck, 28. 9. 1978. (b) Mongolia, Archangai Aimak, Tarbagatai, on basaltic rocks $4 \mathrm{~km}$ west of the Solon-Got pass, alt. ca. $2500 \mathrm{~m}$; leg. et det. S. Huneck, 1. 7. 1978.

Extraction. (a) The air-dried and ground lichen (405 g) was extracted (4 days) with $\mathrm{Et}_{2} \mathrm{O}$ and the extract treated as described by Bruun and Lamvik [1]. The fraction insoluble in cold benzene yielded (+)-usnic acid $(18.27 \mathrm{~g}, 4.5 \%)$ and divaricatic acid, while the more soluble fraction gave after crystallization from benzene haemoventosin (3) as redbrown crystals with m.p. $202-204^{\circ}(0.3 \mathrm{~g}, 0.07 \%)$. $\mathrm{C}_{15} \mathrm{H}_{12} \mathrm{H}_{7}$ (found $m / z$ 304.25). (b) The lichen $(694 \mathrm{~g})$ was treated as above and yielded (+)-usnic acid $(25.4 \mathrm{~g}, 3.65 \%)$, diffractaic acid $(1.76 \mathrm{~g}$, $0.25 \%)$ and haemoventosin $(1.05 \mathrm{~g}, 0.15 \%)$.

Monoacetylhaemoventosin (4). Haemoventosin $(0.3 \mathrm{~g})$ was treated with a mixture $(3 \mathrm{ml})$ of acetic anhydride $(6 \mathrm{ml})$ and conc. sulphuric acid (1 drop) at $20^{\circ}$ and left for 24 hours. The usual work-up, chromatography over silica gel and crystallization from methanol gave yellow needles, m.p. 203- $204^{\circ}$ (dec.), lit. [1] m.p. $193-194^{\circ}$ (dec.). $\mathrm{C}_{17} \mathrm{H}_{14} \mathrm{O}_{8}$ (found $m / z$ 346.28). $[\alpha]_{578}{ }^{24}+354.5\left(^{2} \mathrm{CHCl}_{3}, \mathrm{c}\right.$ 1.145). IR, $v_{\max }{ }^{\mathrm{KBr}}\left(\mathrm{cm}^{-1}\right): 724,752,780,792,826$, 882, 958, 1012, 1066, 1114, 1190, 1220, 1307, 1368, $1426,1606,1634,1716,1750,2950,3480$. MS, $\mathrm{m} / z$ $348\left(35 \%, \mathrm{M}^{+}+2 \mathrm{H}\right), 346\left(30, \mathrm{M}^{+}\right), 306(97), 304$ (100), 302 (78), 289 (67), 288 (92), 273 (40), 260 (43), 245 (30).

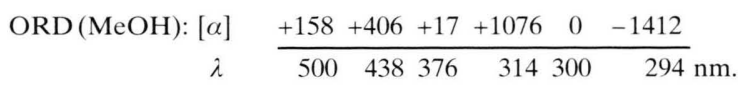

\section{Acknowledgements}

We are grateful to Prof. Dr. G. Snatzke $(\dagger)$, University of Bochum, Prof. Dr. A. Zeeck, University of Göttingen, and Dr. M. Müller, University of Munich, for the CD spectra of $10-O$-acetylhaemoventosin and 10-O-acetyl-semi-xanthomegnin and their interpretation, and Dr. J. Schmidt, Institute of Plant Biochemistry Halle/Saale, for numerous mass spectra and the GLC analysis of the fatty acids from $O$. ventosa. S. Huneck thanks the Fonds der Chemischen Industrie, Frankfurt/Main, for financial support.
[1] T. Bruun, A. Lamvik, Acta Chem. Scand. 25, 483 (1971).

[2] O. B. Maksimov, R. P. Gorschkova, L. S. Stepanenko, N. P. Mischenko, O. E. Krivoschekova, Khim. Prir. Soedin. 400 (1990) (in Russian); C. A. 114, 78633 a (1991).

[3] T. Hanumaiah, G. S. R. Rao, C. P. Rao, K. V. J. Rao, H. J. Cowe, P. J. Cox, R. A. Howie, D. S. Marshall, R. H. Thomson, Tetrahedron 41, 635 (1985).

[4] J. C. Tchouankeu, E. Tsamo, B. L. Sondengam, J. D. Connolly, D. S. Rycroft, Tetrahedron Lett. 31, 4505 (1990).

[5] D. S. Rycroft, Studies in Natural Products Chemistry, Volume 9, Structure and Chemistry (Part B), Atta-ur-Rahman ed., Elsevier, Amsterdam (ISBN 044489165X), 93 (1991).

[6] L. Müller, J. Am. Chem. Soc. 101, 4481 (1979).

[7] H. Kessler, C. Griesinger, J. Zarbock, H. R. Loosli, J. Magn. Reson. 58, 331 (1984).
[8] A. Bax, M. F. Summers, J. Am. Chem. Soc. 108, 2093 (1986).

[9] S. K. Talapatra, S. Bose, A. K. Mallik, B. Talapatra, Tetrahedron 41, 2765 (1985).

[10] A. Zeeck, P. Ruß, H. Laatsch, W. Loeffler, H. Wehrle, H. Zähner, H. Holst, Chem. Ber. 112, 957 (1979).

[11] D. Parisot, M. Devys, J.-P. Férézou, M. Barbier, Phytochemistry 22, 1301 (1983).

[12] D. Parisot, M. Devys, M. Barbier, Phytochemistry 27, 3002 (1988).

[13] R. W. Rogers, J. Hafellner, Lichenologist 20, 167 (1988).

[14] S. Huneck, C. F. Culberson, W. L. Culberson, J. A. Elix, Phytochemistry 30, 706 (1991).

[15] S. Huneck, U. Himmelreich, J. Schmidt, V. John, U. Zeybek, Z. Naturforsch. 49b, 1561 (1994). 